\title{
Prevalence of thermoduric bacteria and spores in nonfat dry milk powders of Midwest origin
}

\author{
Kimberly P. Buehner, ${ }^{*}$ Sanjeev Anand, ${ }^{* 1}$ and Gemechis D. Djira† \\ *Midwest Dairy Foods Research Center, Dairy Science Department, and \\ †Department of Mathematics and Statistics, South Dakota State University, Brookings 57007
}

\begin{abstract}
Samples of nonfat dry milk powder were analyzed for the presence of heat-resistant bacteria. The samples were collected from Midwest manufacturing companies and were evaluated for the presence of spores, thermoduric bacteria, and the total bacterial count. Three companies were included in this study, and results showed differences between each of the companies in the heat-resistant microbial groups tested. Company 3 had the highest levels of total spores and thermoduric bacteria: $3.6 \pm 0.14$ and $3.5 \pm 0.13 \log \mathrm{cfu} / \mathrm{g}$, respectively. Interestingly, this company did not have the highest total bacterial count but rather the second lowest total bacterial count for the group, perhaps because of the higher proportion of thermophiles present in the powders from this company. The average level of total bacterial counts was $2.57 \pm 0.07 \mathrm{log} \mathrm{cfu} / \mathrm{g}$. Isolates obtained from the samples were identified by mass spectrometry, and all of the companies showed Bacillus licheniformis as the most prevalent bacterial species identified.
\end{abstract}

Key words: spore, thermoduric bacteria, highly heatresistant spores, Bacillus

\section{INTRODUCTION}

Several Bacillus species are commonly present in milk at all stages of processing (Crielly et al., 1994; Scheldeman et al., 2005) and, along with other thermoduric organisms, have the potential to contaminate processed dairy products. Aerobic bacterial counts in milk powders include thermophilic bacilli, such as $B a$ cillus, Anoxybacillus, and Geobacillus, for which, realtime PCR assays have been developed (Rückert et al., 2006). Such bacteria with the ability to form spores (SP) pose a challenge to the quality of milk and milk products. Spores are essentially dormant cells that can germinate, or become activated, in very short periods

Received September 4, 2014.

Accepted January 10, 2015.

${ }^{1}$ Corresponding author: Sanjeev.anand@sdstate.edu and produce fully functioning viable cells (Doyle et al., 1997). In these dormant cells, the spore-coat consists of a complex protein structure that is not found in vegetative cells (Driks, 2002; Henriques and Morgan, 2007). The thickness of the spore-coat varies between species, as does the actual chemical and physical make-up of this structure. Different species of SP will have varying degrees of resistance to cleaning agents, adverse $\mathrm{pH}$, and temperatures, along with other unideal environmental conditions capable of damaging vegetative cells (Doyle et al., 1997; Driks 2002). Some of the SP are capable of surviving not only pasteurization, but even UHT and spray-drying processes. As such, it becomes important to control raw milk contamination of bacteria with this ability to form SP in the raw milk, which will lead to an improvement in the quality of any dairy products processed from milk.

A previous study took samples of raw milk all the way through pasteurization, concentration, and spray drying to the final end product of skim milk powder (SMP). The levels of thermoduric bacteria (TDB), SP, and psychrotrophs were enumerated (Griffiths et al., 1988). The TDB and SP are not eliminated during powder manufacture and can even become concentrated from the initial counts already present in the raw milk. Another study followed skim milk to final powder manufacture and showed starting levels of thermophilic bacteria ranged from 350 to $3,500 \mathrm{cfu} / \mathrm{mL}$ and $\mathrm{SP}$ from 200 to 2,000 cfu/mL (Murphy et al., 1999). These samples, however, were ready-to-process milk rather than raw milk. Nonetheless, the samples still contained significant amounts of thermophilic bacteria and SP.

A large majority of the bacteria recovered from milk powders are classified under the Bacillus species. In a large study encompassing powders from 18 different countries, $92 \%$ of the bacteria recovered from the samples were classified as Geobacillus stearothermophilus, Bacillus licheniformis, and Anoxybacillus flavithermus (Rückert et al., 2004). Bacillus subtilis has also been found to be a fairly ubiquitous microorganism in global milk powders (Ronimus et al., 2003). These strains can grow at elevated temperatures and are classified as thermophilic bacteria, which allows them to prolifer- 
ate even during milk processing. Some areas such as the regeneration sections of the evaporator, preheater, and heat exchangers, among others, lie within optimum growing temperatures for thermophiles such as these (Murphy et al., 1999; Scott et al., 2007; Gleeson et al., 2013). It has also been reported that the sporeforming bacteria are able to grow during the holding period between milk powder recombining and UHT processing; however, the level of SP remain the same if the holding period is less than $8 \mathrm{~h}$ (Schwarzenbach and Hill, 1999). Other studies have commonly identified strains of $G$. stearothermophilus, A. flavithermus, and B. subtilis, along with $B$. licheniformis, as contaminants in milk powders from several European countries (Rückert et al., 2004).

A study conducted with samples from 4 different US powder-manufacturing companies tested the levels of sporeformers, thermophiles, and coliforms in nonfat dry milk (NFDM) and SMP. The study found that in low-heat NFDM and SMP, thermophilic sporeformers reached a maximum of $4.1 \mathrm{log} \mathrm{cfu} / \mathrm{g}$ and thermophilic bacteria numbers ranged from 2.0 to $2.9 \mathrm{log} \mathrm{cfu} / \mathrm{g}$. All of the NFDM and SMP samples contained $<10 \mathrm{cfu} / \mathrm{g}$ for coliforms, thermoresistant bacteria, and yeasts and molds (Ali et al., 2013). No set standards in the United States exist for milk powders as far as acceptable levels of thermophilic bacteria or sporeformers, but general quality parameters exist in the industry limiting thermophilic sporeformers to a maximum of $2,000 \mathrm{cfu} / \mathrm{g}$, thermophilic bacteria to $<10,000 \mathrm{cfu} / \mathrm{g}$, and thermoresistant $\mathrm{SP}\left(100^{\circ} \mathrm{C}, 30 \mathrm{~min}\right)$ to $<500 \mathrm{cfu} / \mathrm{g}$ (Wehr and Frank, 2004). Because no current standards exist, the variability in levels of TDB and sporeformers (thermophilic and mesophilic) present in NFDM, SMP, and other milk powders needs to be studied more in depth to establish an industry standard. Such standards are important to the dairy industry because after reconstitution of milk powders, SP are more likely to return to their vegetative state because of higher water content, which is vital for any form of vegetative growth and proliferation. The integrity of any reconstituted milk powder is a product of water quality and processing conditions, along with the original microbial content of the milk powder among other considerations.

This study was performed to identify heat-tolerant bacterial contaminants in milk powders produced in the Midwest region and to enumerate total bacteria counts (TBC), SP, and TDB present in dairy powders. Because the bacterial contaminants in raw milk are quite variable because of regional differences in climate, strategies used to reduce the levels of heat-tolerant bacterial contaminants in NFDM will vary depending on source of raw milk and processing conditions. This study encompasses the first step of this process, which is the identification and enumeration of potential milkpowder contaminants in the Midwest region.

\section{MATERIALS AND METHODS}

\section{Source of Powder Samples}

Nonfat dry milk samples were obtained from 3 powder-manufacturing companies operating in the Midwest region and were representative of a total of 39 lots (company 1, 11 lots; company 2, 18 lots; company 3, 10 lots). The samples were organized by lot numbers and stored at room temperature until analysis.

\section{Sample Preparation}

From samples collected, subsamples of $11 \pm 0.2 \mathrm{~g}$ samples were weighed out and dissolved into $99 \mathrm{~mL}$ of $2 \%$ sodium citrate (Remel, Thermo Scientific, Waltham, $\mathrm{MA}$ ). The diluent was warmed to about $50^{\circ} \mathrm{C}$ before the experiment to improve the solubility of the powder samples. The samples were split into equal $30-\mathrm{mL}$ portions and placed into sterile screw-cap tubes. The tubes were subjected to the following heat treatments: $63 \pm$ $0.5^{\circ} \mathrm{C}$ for $30 \mathrm{~min}(\mathrm{TDB})$ and $80 \pm 0.5^{\circ} \mathrm{C}$ for $12 \mathrm{~min}$ (SP). The remaining sample was plated in duplicate without heat treatment for TBC. The heat-treated samples were cooled in an ice bath for 10 min before plating (Downes and Ito, 2001).

\section{Microbiological Analysis}

The samples were diluted using phosphate buffer solution and plated using brain heart infusion (Remel) agar using the pour plating technique. From each heat treatment the samples were directly plated in duplicate and incubated at $32^{\circ} \mathrm{C}$ (mesophilic counts for TDB and $\mathrm{SP}$ ) and $55^{\circ} \mathrm{C}$ (thermophilic counts for TDB and SP) for $48 \mathrm{~h}$ before enumeration to give as much recovery time as possible to potentially allow injured cells to grow. The TBC plates were incubated only at $32^{\circ} \mathrm{C}$ for $48 \mathrm{~h}$. Each lot was plated in triplicate with the average of these trials reported as the lot count, and for each company, lot counts were averaged to report manufacturer's counts.

\section{Isolate Identification}

Morphologically different colonies numbering 60 total were randomly selected from the plates from each heat treatment and company. The isolates were sent to the Animal Disease Research and Diagnostic Laboratory at South Dakota State University to be identified through matrix-assisted laser desorption/ionization 
Table 1. Overall bacterial and spore counts in samples of nonfat dried milk

\begin{tabular}{|c|c|c|c|c|}
\hline $\begin{array}{l}\text { Sample } \\
\text { source }\end{array}$ & $\begin{array}{l}\text { No. of } \\
\text { lots }\end{array}$ & $\begin{array}{c}\text { Total bacterial } \\
\text { counts }^{1}(\log \mathrm{cfu} / \mathrm{g})\end{array}$ & $\begin{array}{l}\text { Total spores } \\
(\log \mathrm{cfu} / \mathrm{g})\end{array}$ & $\begin{array}{l}\text { Total thermoduric } \\
\text { bacteria }(\log \mathrm{cfu} / \mathrm{g})\end{array}$ \\
\hline Company 1 & 11 & $2.4 \pm 0.07^{\mathrm{a}}$ & $3.1 \pm 0.11^{\mathrm{b}}$ & $3.3 \pm 0.12^{\mathrm{b}}$ \\
\hline Company 2 & 18 & $2.8 \pm 0.12^{\mathrm{a}}$ & $3.1 \pm 0.16^{\mathrm{a}}$ & $3.0 \pm 0.18^{\mathrm{a}}$ \\
\hline Company 3 & 10 & $2.4 \pm 0.14^{\mathrm{a}}$ & $3.6 \pm 0.14^{\mathrm{b}}$ & $3.5 \pm 0.13^{\mathrm{b}}$ \\
\hline Mean $( \pm \mathrm{SE})$ & & $2.57 \pm 0.07^{\mathrm{a}}$ & $3.24 \pm 0.09^{\mathrm{b}}$ & $3.23 \pm 0.10^{\mathrm{b}}$ \\
\hline
\end{tabular}

and time-of-flight mass spectrometry (Bruker Daltonics Biflex IV MALDI-TOF MS, Billerica, MA). Prior to identification, isolates were freshly grown overnight on tryptic soy agar (Remel) infused with $5 \%$ sheep blood. Cultures were tested immediately after incubation to preserve the integrity of ribosomal proteins.

\section{Statistical Analysis}

Poisson regression with adjustment for overdispersion was performed using PROC GENMOD procedure of SAS 9.3 software (SAS Institute Inc., Cary, NC). For models with categorical variables with more than 2 possible outcomes, the Tukey-Kramer multiple-comparison procedure was used for multiplicity adjustment in pairwise comparisons. A random effects model was used to assess company-to-company variations.

\section{RESULTS AND DISCUSSION}

\section{TBC}

The average TBC obtained for each of the companies ranged from 2.4 to $2.8 \mathrm{log} \mathrm{cfu} / \mathrm{g}$, which is primarily due to the single $32^{\circ} \mathrm{C}$ incubation temperature only, whereas the other total thermoduric bacterial counts are a combination of 32 and $55^{\circ} \mathrm{C}$ incubation temperatures (Table 1). The TBC reflects a baseline of levels of bacteria that are not necessarily heat resistant or heat tolerant. In comparison, levels of thermophiles, in general, were higher than mesophiles across all of the types (Tables 2 and 3). Levels of TBC are in the same range as the averages for the mesophilic counts alone. A previous study in the United States reported the TBC in NFDM and SMP had a range of 2.0 to 2.9 $\log \mathrm{cfu} / \mathrm{g}$ with differences due to powder manufacturers (Ali et al., 2013). This study also concluded that the microbiological quality of powders was source dependent regardless of heat classification.

\section{$S P$}

The bacterial SP, inclusive of thermophiles and mesophiles, were in general similar to the TDB counts in the powder samples (Table 1). The maximum average SP count achieved was the thermophilic SP count from company 3 at $3.5 \log \mathrm{cfu} / \mathrm{g}$ comparative to 2.9 and 3.0 $\log \mathrm{cfu} / \mathrm{g}$ for both of the remaining companies (Table 2). A previous study conducted at the University of Wisconsin-Madison also studied NFDM and SMP powders and showed a range from $<1$ to $4.1 \mathrm{log} \mathrm{cfu} / \mathrm{g}$ of thermophilic SP (Ali et al., 2013). This study also selectively focused on US powders and included samples from 4 different manufacturing companies.

The mesophilic SP counts were $2.3 \mathrm{log} \mathrm{cfu} / \mathrm{g}$ and were significantly lower $(P<0.01)$ than the thermophilic counts. It is logical that heat-resistant bacteria present in milk-processing plants would tend to be thermophiles because of the higher processing temperatures (Scott et al., 2007; Gleeson et al., 2013). Company 3 had the highest total level of SP at $3.6 \pm 0.14 \mathrm{log} \mathrm{cfu} / \mathrm{g}$ among the 3 companies included in this study. In this

Table 2. Mesophilic and thermophilic spore counts in samples of nonfat dried milk ${ }^{1}$

\begin{tabular}{|c|c|c|c|c|}
\hline \multirow{2}{*}{$\begin{array}{l}\text { Sample } \\
\text { source }\end{array}$} & \multirow[b]{2}{*}{ No. of lots } & \multicolumn{3}{|c|}{ Spores (log cfu/g) } \\
\hline & & Mesophilic & Thermophilic & Total \\
\hline Company 1 & 11 & $2.3 \pm 0.04^{\mathrm{a}}$ & $3.0 \pm 0.15^{\mathrm{b}}$ & $3.1 \pm 0.11$ \\
\hline Company 2 & 18 & $2.3 \pm 0.03^{\mathrm{a}}$ & $2.9 \pm 0.20^{\mathrm{b}}$ & $3.1 \pm 0.16$ \\
\hline Company 3 & 10 & $2.3 \pm 0.08^{\mathrm{a}}$ & $3.5 \pm 0.16^{\mathrm{b}}$ & $3.6 \pm 0.14$ \\
\hline Mean $( \pm \mathrm{SE})$ & & $2.32 \pm 0.03^{\mathrm{a}}$ & $3.09 \pm 0.11^{\mathrm{b}}$ & $3.24 \pm 0.09$ \\
\hline
\end{tabular}


Table 3. Mesophilic and thermophilic thermoduric bacterial counts in samples of nonfat dried milk

\begin{tabular}{lcccc}
\hline & & \multicolumn{3}{c}{ Thermoduric bacteria (log cfu/g) } \\
\cline { 3 - 5 } Sample source & No. of lots & Mesophilic & Thermophilic $^{1}$ & \multicolumn{1}{c}{ Total } \\
\hline Company 1 & 11 & $2.1 \pm 0.05^{\mathrm{a}}$ & $3.3 \pm 0.13^{\mathrm{b}}$ & $3.3 \pm 0.12$ \\
Company 2 & 18 & $2.2 \pm 0.05^{\mathrm{a}}$ & $2.8 \pm 0.22^{\mathrm{b}}$ & $3.0 \pm 0.18$ \\
Company 3 & 10 & $2.3 \pm 0.09^{\mathrm{a}}$ & $3.5 \pm 0.15^{\mathrm{b}}$ & $3.5 \pm 0.13$ \\
Mean ( \pm SE) & & $2.19 \pm 0.03^{\mathrm{a}}$ & $3.11 \pm 0.12^{\mathrm{b}}$ & $3.23 \pm 0.10$ \\
\hline
\end{tabular}

$\overline{\mathrm{a}, \mathrm{b}}$ Different superscripts within a row indicate significant differences $(P<0.005)$.

${ }^{1}$ Significant company-to-company variation at the $5 \%$ level.

study, samples were heat treated at $80 \pm 0.5^{\circ} \mathrm{C}$ for 12 min for SP, but some other protocols have used $85^{\circ} \mathrm{C}$ up to 30 min (Furukawa et al., 2005); therefore, a direct comparison is not possible. The incidence of higher thermophilic rather than mesophilic SP (Table 2) may potentially cause further issues after the reconstitution of the NFDM powders. Thermophilic SP have a higher likelihood of proliferation during commercial processing, which takes place above growth ranges for classified mesophiles but at thermophilic optimum growth temperatures (Rückert et al., 2004).

\section{$T D B$}

Thermoduric bacteria could be predominantly classified as thermophilic (Table 3) with counts ranging from 2.8 to $3.5 \log \mathrm{cfu} / \mathrm{g}$. Company 3 had the highest level of total TDB at $3.5 \pm 0.13 \log \mathrm{cfu} / \mathrm{g}$, and company $2 \mathrm{had}$ the lowest at $3.0 \pm 0.18 \mathrm{log} \mathrm{cfu} / \mathrm{g}$. Total TDB counts differed between all of the manufacturing companies. If acceptable levels of TDB and SP are to be standardized throughout the United States, the clean-in-place (CIP) procedures and chemicals used may also need some further evaluation along with new technologies. The overall goal is to provide a baseline of information on these TDB and SP, so that the industry can optimize processes and practices to control these. The specific makes and procedures of the powders can be kept trade secrets, but it may be beneficial to optimize and continue improving dry and wet CIP procedures that result in lower counts and long shelf-life powders that contain few heat-resistant bacteria.

Contamination in milk powders has implications if the powders are intended for reconstitution. Milk powders such as NFDM may be used for a variety of products, but if the powders are not properly heat treated after reconstitution, the quality and shelf stability of the final product will be somewhat decreased. Although the majority of heat-resistant bacterial contaminants will not produce life-threatening toxins, concern remains for food safety in addition to quality issues.

\section{Identification of Bacteria Isolates}

Other studies have found A. flavithermus and $G$. stearothermophilus as the predominant species in milk powders (Ronimus et al., 2003; Rückert et al., 2004), of which A. flavithermus has even been found to rapidly grow and form both biofilms and SP simultaneously (Burgess et al., 2009). In our study, B. licheniformis was predominantly identified among isolates from each of the 3 companies (Table 4) using matrix-assisted laser desorption/ionization and time-of-flight, which compares well with the conventional identification techniques. It was also the most common species identified among isolates in TDB and SP categories, indicating the versatility of $B$. licheniformis (Table 4). Among 60 bacterial isolates identified in this study, $63 \%$ were identified as B. licheniformis. Geobacillus stearothermophilus was represented in $7 \%$ of the identified isolates overall, but it was only found in 1 of 3 companies, suggesting that this species could be a company-specific and not a region-specific contaminant (Table 4). Bacillus sonorensis was identified in $10 \%$ of the overall samples but was also only identified at one of the companies, marking it as a company-specific contaminant (Table 4). In fact, only B. licheniformis was identified in all of the 3 companies, indicating that this species could be the most common one in NFDM powder in the Midwest region. Bacillus pumilus was present at 2 of the 3 companies and in $10 \%$ of the samples. Company 3 had the largest variety of bacteria isolates identified, with 5 different species identified in 3 of the different heat-treatment categories, whereas the other 2 companies only had 4 different species with positive identifications.

The variety of NFDM-powder bacterial contaminants is quite limited mostly because the harsh processing conditions select for only those capable of surviving it. Geobacillus spp. and A. flavithermus have been identified to be the most common thermophilic contaminants found in milk powders (Flint et al., 2001; Ronimus et al., 2003; Burgess et al., 2009). Bacillus licheniformis contains proteolytic enzymes so the presence of this specific isolate could potentially be detrimental to the 
Table 4. Distribution of bacterial species in 39 samples of nonfat dried milk as identified using matrix-assisted laser desorption ionization and time-of-flight mass spectrometry

\begin{tabular}{lcccc}
\hline Bacterial species & Company 1 & Company 2 & Company 3 & Total \\
\hline Bacillus altitudinis & & & 1 & 1 \\
Bacillus cereus & 17 & 10 & 1 & 1 \\
Bacillus licheniformis & 1 & & 11 & 38 \\
Bacillus megaterium & 1 & 6 & 5 & 6 \\
Bacillus pumilus & & 1 & 4 & 6 \\
Bacillus sonorensis & & 1 & 4 \\
Clostridium halophilum & & & \\
Geobacillus stearothermophilus & 1 & & 1 \\
Klebsiella oxytoca & & & 60 \\
Oceanobacillus spp. & & & \\
Total & & & \\
\hline
\end{tabular}

integrity of milk powders, which are high in proteins. Pinpointing B. licheniformis as the dominant contaminant in raw milk (Buehner et al., 2014) and powders in the Midwest region indicates the importance of this organism in milk powders. This study, thus, provides important information for potentially targeting the CIP system to decrease such contamination of milk powders and design approaches to contain it in raw milk itself.

\section{CONCLUSIONS}

The levels of SP and TDB were relatively similar at $3.24 \pm 0.09$ and $3.23 \pm 0.10 \log \mathrm{cfu} / \mathrm{g}$, respectively. The incidence of SP is of some concern because they are able to resist the heat treatments and are harder to eradicate with traditional heat treatments generally employed in dairy processing. Currently in the United States, no common guidelines are accepted by the dairy industry regarding nonpathogenic heat-stable bacteria and SP such as the ones reported here. Therefore, this study contributes toward data compilation to work toward implementing a nationwide standard or grade levels of standards for milk powders. However, more studies still need to be conducted across different regions of the United States to compare the regional variations and allow for fair comparisons to studies conducted in different countries. To better compete with the milk-powder trade of Europe and other countries, the American industry can benefit from understanding the limitations of the current system by gaining further knowledge about current levels of TDB and SP in the final powder products. Only after more information is known can effective guidelines and management practices be established. Application of other methods such as microfiltration, cavitation, and so on, in combination with pasteurization and other heat treatments that could target the reduction of $B$. licheniformis specifically, should be studied in greater detail to potentially reduce this most common heat-stable contaminant in milk powders.

\section{ACKNOWLEDGMENTS}

The authors acknowledge Lloyd Metzger (Dairy Science Department, South Dakota State University, Brookings) for his assistance in obtaining samples and Seema Das (Animal Disease Research and Diagnostic, South Dakota State University, Brookings) and her laboratory for their assistance in identifying the bacterial isolates by matrix-assisted laser desorption ionization and time-of-flight mass spectrometry. Howard Bonnemann (Dairy Plant, South Dakota State University, Brookings) is acknowledged for reading the manuscript for internal review. The authors also acknowledge the support of the Agricultural Experiment Station, South Dakota State University, in conducting the study.

\section{REFERENCES}

Ali, A. K. A., K. E. Smith, K. J. Burrington, and J. A. Lucey. 2013. Microbiological quality of nonfat dry milk and skim milk powder produced in the United States. ADSA Poster T290. J. Dairy Sci. 96(E-Suppl. 1):101.

Buehner, K. P., S. Anand, and A. Garcia. 2014. Prevalence of thermoduric bacteria and spores on 10 Midwest dairy farms. J. Dairy Sci. 97:8009-8016.

Burgess, S. A., J. D. Brooks, J. Rakonjac, K. M. Walker, and S. H. Flint. 2009. The formation of spores in biofilms of Anoxybacillus flavithermus. J. Appl. Microbiol. 107:1012-1018.

Crielly, E. M., N. A. Logan, and A. Anderton. 1994. Studies on the Bacillus flora of milk and milk products. J. Appl. Bacteriol. $77: 256-263$.

Downes, F. P., and K. Ito. 2001. Compendium of Methods for the Microbiological Examination of Foods. 4th ed. Am. Pub. Health Assoc., Washington, DC.

Doyle, M. P., L. R. Beuchat, and T. J. Montville. 1997. Food Microbiology: Fundamentals and Frontiers. Vol. XVI. ASM Press, Washington, DC. Pages 768-784.

Driks, A. 2002. Overview: Development in bacteria: Spore formation in Bacillus subtilis. Cell. Mol. Life Sci. 59:389-391.

Flint, S., J. Palmer, K. Bloeman, J. Brooks, and R. Crawford. 2001. The growth of Bacillus stearothermophilus on stainless steel. J. Appl. Microbiol. 90:151-157.

Furukawa, S., N. Narisawa, T. Watanabe, T. Kawarai, K. Myozen, S. Okazaki, H. Ogihara, and M. Yamasaki. 2005. Formation of the spore clumps during heat treatment increases the heat resistance of bacterial spores. Int. J. Food Microbiol. 102:107-111. 
Gleeson, D., A. O'Connell, and K. Jordan. 2013. Review of potential sources and control of thermoduric bacteria in bulk-tank milk. Ir. J. Agric. Food Res. 52:217-227.

Griffiths, M. W., J. D. Phillips, I. G. West, A. W. M. Sweetsur, and D. D. Muir. 1988. The quality of skim-milk powder produced from raw milk stored at $2^{\circ} \mathrm{C}$. Food Microbiol. 5:89-96.

Henriques, A. O., and C. P. J. Morgan. 2007. Structure, assembly, and function of spore surface layers. Annu. Rev. Microbiol. 61:555588.

Murphy, P. M., D. Lynch, and P. M. Kelly. 1999. Growth of thermophilic spore forming bacilli in milk during the manufacture of low heat powders. Int. J. Dairy Technol. 52:45-50.

Ronimus, R. S., L. E. Parker, N. Turner, S. Poudel, A. Ruckert, and H. W. Morgan. 2003. A RAPD-based comparison of thermophilic bacilli from milk powders. Int. J. Food Microbiol. 85:45-61.

Rückert, A. R., S. Ronimus, and H. W. Morgan. 2004. A RAPD-based survey of thermophilic bacilli in milk powders from different countries . Int. J. Food Microbiol. 96:263-272.
Rückert, A. R., S. Ronimus, and H. W. Morgan. 2006. Development of real-time PCR assay targeting the sporulation gene, spo0A, for the enumeration of thermophilic bacilli in milk powder. Food Microbiol. 23:220-230.

Scheldeman, P., A. Pil, L. Herman, P. De Vos, and M. Heyndrickx. 2005. Incidence and diversity of potentially highly heat-resistant spores isolated at dairy farms. Appl. Environ. Microbiol. 71:1480-1494

Schwarzenbach, R., and B. M. Hill. 1999. Do bacterial spores in milk powders survive UHT processing? Pages 156-162 in Proc. 3rd Int. Symp. Recomb. Milk Milk Prod. Int. Dairy Fed., Brussels, Belgium.

Scott, S. A., J. D. Brooks, J. Rakonjac, K. M. R. Walker, and S. H. Flint. 2007. The formation of thermophilic spores during the manufacture of whole milk powder. Int. J. Dairy Technol. 60:109-117.

Wehr, H. M., and J. Frank. 2004. Standard Methods for the Examination of Dairy Products. 17th ed. Am. Pub. Health Assoc., Washington, DC. 